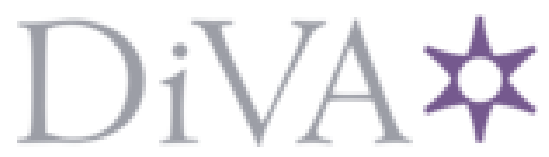

http://www.diva-portal.org

\title{
Postprint
}

This is the accepted version of a paper published in American Journal of Political Science. This paper has been peer-reviewed but does not include the final publisher proof-corrections or journal pagination.

Citation for the original published paper (version of record):

Dawes, C., Cesarini, D., Fowler, J., Johannesson, M., Magnusson, P. et al. (2014)

The Relationship Between Genes, Psychological Traits, and Political Participation.

American Journal of Political Science, 58(4): 888-903

http://dx.doi.org/10.1111/ajps.12100

Access to the published version may require subscription.

N.B. When citing this work, cite the original published paper.

Permanent link to this version:

http://urn.kb.se/resolve?urn=urn:nbn:se:uu:diva-2 19244 
RUNNING HEAD: Genes, Psychological Traits, and Participation

\section{The Relationship Between Genes, Psychological Traits, and}

\section{Political Participation*}

\author{
Christopher Dawes \\ cdawes@nyu.edu \\ New York University \\ 19 W. 4th Street, 2nd Floor \\ New York, NY 10012 \\ James H. Fowler \\ fowler@ucsd.edu \\ University of California, San Diego \\ Social Science Building 392 \\ 9500 Gilman Drive \#0521 \\ La Jolla, CA 92093-0521 \\ Patrik KE Magnusson \\ patrik.magnusson@ki.se \\ Karolinska Institutet \\ SE-102 Stockholm, Sweden
}

\author{
David Cesarini \\ david.cesarini@nyu.edu \\ New York University \\ 19 W. 4th Street, 6th Floor \\ New York, NY 10012 \\ Magnus Johannesson \\ magnus.johannesson@hhs.se \\ Stockholm School of Economics \\ SE-113 83 Stockholm, Sweden
}

\author{
Sven Oskarsson \\ sven.oskarsson@statsvet.uu.se \\ Uppsala University \\ 75120 Uppsala, Sweden
}

Keywords: political participation; cognitive ability; extraversion; personal control;

behavior genetics; heritability

\footnotetext{
*We thank the Jan Wallander and Tom Hedelius Foundation and the Swedish Council for Working Life and Social Research for financial support. The Swedish Twin Registry is supported by grants from the Swedish Research Council and the Ministry for Higher Education.
} 


\begin{abstract}
Recent research demonstrates that a wide range of political attitudes, beliefs, and behaviors can be explained in part by genetic variation. However, these studies have not yet identified the mechanisms that generate such a relationship. Some scholars have speculated that psychological traits mediate the relationship between genes and political participation, but so far there have been no empirical tests. Here we focus on the role of three psychological traits that are believed to influence political participation: cognitive ability, personal control, and extraversion. Utilizing a unique sample of more than 2,000 Swedish twin pairs, we show that a common genetic factor can explain most of the relationship between these psychological traits and acts of political participation as well as predispositions related to participation. While our analysis is not a definitive test, our results suggest an upper bound for a proposed mediation relationship between genes, psychological traits, and political participation.
\end{abstract}




\section{Introduction}

Motivated by earlier research showing a genetic basis for political attitudes (Martin et al. 1986, Alford, Funk \& Hibbing 2005), researchers recently discovered that political behaviors like voter turnout and other acts of political participation are also influenced by genetic variation (Fowler, Baker \& Dawes 2008). These findings raise the question of how genes and political participation are linked. Mondak (2010) suggested that personality traits may intermediate the relationship between genes and political participation, a conjecture that is potentially supported by recent scholarship demonstrating a relationship between personality traits and political participation (Gerber et al. 2011, Mondak et al. 2010, Mondak 2010, Blais \& St-Vincent 2011, Vecchione \& Caprara 2009, Mondak \& Halperin 2008, Denny \& Doyle 2008, Gallego \& Oberski 2012). However, an empirical link between genes, personality traits, and political participation has yet to be established. This article seeks to explore the relationship between all three using a uniquely assembled and comprehensive genetically informative dataset with information on personality, cognitive ability and a wide range of political attitudes, beliefs and behaviors. We focus on three potential intermediate psychological traits identified by the literature: cognitive ability, personal control, and extraversion.

In order to investigate a relationship between genes, psychological traits, and political participation it is necessary to move from a univariate to a bivariate framework of analysis. The primary bivariate model we employ, a Cholesky decomposition model, allows us to estimate the genetic contribution to the observed covariation between political participation and psychological traits. ${ }^{1}$ However, while the Cholesky model shows that political participation and the three

\footnotetext{
${ }^{1}$ Medland \& Hatemi (2009) provide a detailed description of the Cholesky model geared toward a political science audience. The Cholesky decomposition has also been utilized in several recently published political science studies
} 
psychological traits we study are genetically related, it is limited in that it does not allow us to adjudicate between different types of possible relationships. Psychological traits may mediate the relationship between genes and political participation, however alternatively psychological traits and political participation may share the same underlying genetic mechanism but do not share a causal relationship (Posthuma et al. 2003). ${ }^{2}$ The latter scenario, known as pleiotropy, implies that genetic factors are a confounder.

To preview our results, we demonstrate that both acts of participation and related political predispositions share a common source of genetic variation with psychological traits. However, the three psychological traits we study account for only a modest amount of the heritable variation in political participation and predispositions. If psychological traits are in fact mediators, as has been hypothesized by other scholars (Mondak et al. 2010, Mondak 2010), a majority of the heritable variation in political participation and predispositions is likely mediated by traits other than cognitive ability, personal control, and extraversion. Finally, we attempt to test the nature of the relationship between genes, psychological traits, and political participation using a Direction of Causation model (Heath et al. 1993, Duffy \& Martin 1994). ${ }^{3}$

Our work aims to address a fundamental question in political science, namely why some individuals participate in politics whereas others do not. One answer to this question is that genetic variation can ultimately explain a moderate to large share of individual differences in these behaviors. However, this begs the important question of how genes influence political behaviors.

(Hatemi et al. 2009b, Littvay, Weith \& Dawes 2011, Weber, Johnson \& Arceneaux 2011, Arceneaux, Johnson \& Maes 2012, Fazekas \& Littvay 2012, Klemmensen et al. 2012, Oskarsson et al. 2012).

${ }^{2}$ These two possible relationships are illustrated by Figure 1 and Figure 2 in the Online Appendix. It may also be the case that political participation causes psychological traits or there is reciprocal causation (Verhulst, Eaves \& Hatemi 2012).

${ }^{3}$ Verhulst, Eaves \& Hatemi (2012) was the first study in political science to utilize the Direction of Causation model. 
This article examines potential mechanisms which have been hypothesized in the literature to mediate the relationship between genetic factors and various acts of political participation and demonstrates the utility of combining methods from behavioral genetics and personality psychology to better understand heterogeneity in political participation. While our analysis is not a definitive test, our results suggest an upper bound for a proposed mediation relationship between genes, psychological traits, and political participation.

\section{Theoretical and Empirical Evidence}

Fowler, Baker \& Dawes (2008) first established a link between genes and political participation based on their analysis of acts such as voting, volunteering in a political club or organization, contributing money to a political party or candidate, contacting a government official regarding political or community issues, running for public office, or attending a political rally or march. The authors found that $60 \%$ of the variation in overall participation could be attributed to genetic factors. Recently a group of scholars found similar heritability estimates for measures of non-voting participation in Denmark and a new US sample (Klemmensen et al. 2012).

While the fact that individual differences in political participation can be traced to genetic variation is interesting, the influence of genes on modern behaviors such as these is likely indirect via more fundamental traits. ${ }^{4}$ Distinguishing between the various mechanisms which might help explain the heritable variation in a trait is an important next step in this research agenda. Scholars studying the effect of personality on political participation and attitudes have argued that since personality traits are formed before political behaviors, and are known to be heritable (Bouchard

\footnotetext{
${ }^{4}$ There are several recent reviews of the genetics of politics (Fowler \& Schreiber 2008, Hatemi et al. 2011, Hatemi \& McDermott 2012, Hatemi, Byrne \& McDermott 2012).
} 
\& McGue 2003), they likely represent an intermediate link in the causal chain (Mondak et al. 2010, Mondak 2010).

The idea that personality traits in part shape political participation can be traced back to The American Voter (Campbell et al. 1960), however a new generation of scholars have begun to rigorously investigate this assertion (Mondak et al. 2010, Gerber et al. 2011, Blais \& St-Vincent 2011, Vecchione \& Caprara 2009, Mondak \& Halperin 2008, Denny \& Doyle 2008, Gallego \& Oberski 2012). ${ }^{5}$ While comprehensive theory linking personality traits to political participation is being actively developed (Mondak \& Halperin 2008, Mondak et al. 2010, Mondak 2010), scholars have consistently argued that traits related to personal control and a willingness to engage in social interaction are likely to influence political participation (Carmines 1980, Carlson \& Hyde 1980, Guyton 1988, Milbrath \& Goel 1977, Cohen, Vigoda \& Samorly 2001, Mondak \& Halperin 2008, Blais \& St-Vincent 2011, Gerber et al. 2011, Mondak et al. 2010, Vecchione \& Caprara 2009).

Campbell et al. (1960) originally argued that differences in one's general feeling of mastery over the self and environment probably translate into the political process as well. Competence theory, developed by Carmines (1980), postulates that personal control promotes political participation. Personal control is the belief that outcomes are the product of one's own efforts. The incentive to engage in any kind of action is predicated on whether or not it can produce a desired outcome. If the outcome is believed to be out of one's control then there is little incentive to undertake an action, especially if it is costly to do so. Competence theory extends this thinking to political engagement. Individuals with high personal control will be motivated to become involved in the political process because their actions will be rewarded with a desired political outcome.

\footnotetext{
${ }^{5}$ The literature studying the personality and political attitudes goes back further to Adorno et al. (1950), Eysenck (1954), and McClosky (1958).
} 
Several studies have found empirical support for competence theory (Carmines 1980, Carlson \& Hyde 1980, Guyton 1988, Milbrath \& Goel 1977). Recent work has also demonstrated an empirical link between self-efficacy, a trait strongly related to personal control (Judge et al. 2002, Bono \& Judge 2003), and political participation. Blais \& St-Vincent (2011) reported a positive relationship between a measure of general self-efficacy and two different indicators of turnout. Self-efficacy and personal control are strongly related concepts; self-efficacy is defined as the belief in one's ability to perform across many different contexts and personal control is the belief in one's ability to control one's environment (Bono \& Judge 2003). However, self-efficacy is a broader concept tapping both control over the environment and a general belief in one's competence so the two concepts are not equivalent. ${ }^{6}$

Mondak \& Halperin (2008) theorize that since social interaction is essential for many political acts, one's general predisposition toward engaging with others should influence one's willingness to participate in politics. This is especially true for acts like attending and speaking at meetings or rallies, signing petitions, and participating in political discussions. In support of this assertion, Mondak et al. (2010) found a significant relationship between the Big Five personality trait extraversion, which is marked by sociability and an eagerness to engage with others, and contacting an elected official, attending public meetings, and attending election rallies. Vecchione \& Caprara (2009) also reported extraversion to be significantly related to overall participation. Finally, Blais \& St-Vincent (2011) found shyness to be inversely related to the propensity to vote.

The assertion that personality traits are causally prior to political traits has recently been

\footnotetext{
${ }^{6}$ The correlation between self-efficacy and personal control is 0.56 (Bono \& Judge 2003). The two questions measure Blais \& St-Vincent (2011) use asks whether respondents agree with the statements "I can do just about anything I really set my mind to" and "I have little control over what happens to me", therefore control is an important part of what the authors are capturing.
} 
challenged (Verhulst, Hatemi \& Martin 2010, Verhulst, Eaves \& Hatemi 2012, Verhulst \& Estabrook 2012). Verhulst, Eaves \& Hatemi (2012), using a genetically informative sample, directly test the hypothesis that personality traits shape political attitudes. The authors argue that the personality traits do not cause political attitudes; in some cases both are driven by common genetic influences while in other attitudes actually cause personality traits or there is reciprocal causation. While no study has conducted a similar analysis for political participation, the findings of Verhulst, Eaves \& Hatemi (2012) suggest caution is required when considering a proposed mediation relationship.

Another possible mediator is cognitive ability. There are various mechanisms through which cognitive ability may influence political participation. One plausible hypothesis is that acts of political participation require the mobilization of costly cognitive resources, whose availability varies across individuals. To undertake a political action, an individual is usually required to acquire and then process information (Luskin 1990). If information gathering and processing is cheaper for those with higher cognitive ability, they will be more likely to participate relative to those with lower cognitive ability.

Individuals with higher cognitive ability may be better at absorbing the political information to which they are exposed in the press and may also endogenously select into environments with more information available. "Preference-based" channels from cognitive ability to political behavior are also plausible. Psychologists and behavioral economists have shown that cognitive ability is associated with high discount rates and other behavioral anomalies (Benjamin, Brown \& Shapiro 2006, Kirby, Winston \& Santiesteban 2005). On this assessment, political participation is an act which entails paying an immediate cost to enjoy instrumental benefits at some later stage (Fowler 
$\& \operatorname{Kam} 2006)^{7}$

Several studies have established a link between cognitive ability, using a variety of different measures, and voter turnout (Hauser 2000, Denny \& Doyle 2008, Deary, Batty \& Gale 2008) as well as overall participation (Verba, Schlozman \& Brady 1995, Nie, Junn \& Stehlik-Barry 1996). As with personality traits, growing empirical evidence supports the assertion that individual differences in cognitive ability are associated with different levels and types of political participation.

Scholars studying the relationship between personality traits and political participation have also argued that this relationship is likely to be indirect, mediated by political predispositions like political interest, feelings of civic duty (Blais \& St-Vincent 2011, Gallego \& Oberski 2012), a desire to acquire political knowledge, and perceived political efficacy (Guyton 1988, Cohen, Vigoda \& Samorly 2001, Mondak et al. 2010, Vecchione \& Caprara 2009, Gallego \& Oberski 2012). In terms of the personality traits we study in this paper, Cohen, Vigoda \& Samorly (2001) and Guyton (1988) showed that personal control influences political participation via political efficacy. Gallego \& Oberski (2012) found that extraversion influences both turnout and engagement in acts of protest via political efficacy and Vecchione \& Caprara (2009) reported that political efficacy fully mediated the effect of extraversion on overall political participation.

There is also empirical evidence that cognitive ability exerts an indirect effect on participation. Verba, Schlozman \& Brady (1995) demonstrated that when including interest in politics, political efficacy, and political information in a regression model of political participation, verbal ability became insignificant suggesting that these variables mediate a relationship between cognitive ability and participation.

\footnotetext{
${ }^{7}$ Individuals may enjoy immediate benefits from seeing one's preferred candidate win or warm-glow utility from doing one's civic duty. However, many of the policy-related benefits are not realized until the future.
} 
On the genetics side, recent work has shown that political efficacy, knowledge, and interest are all heritable based on US and European samples (Klemmensen et al. 2012). Further, Klemmensen et al. (2012) found that most of the covariation between efficacy and political participation could be traced to a common genetic factor. Taken together, this research suggests that psychological traits like cognitive ability, personal control, and extraversion may possibly mediate the relationship between genes and political predispositions known to be strongly related to political participation.

In summary, there is growing empirical evidence that cognitive ability, personal control, and extraversion are associated with political participation as well as political predispositions. Further, scholars have argued that since development of these psychological traits predates coming of age politically, they are causally prior to political participation and predispositions (Mondak et al. 2010, Mondak 2010). This assertion, combined with findings from behavioral genetics that personality traits and cognitive ability are highly heritable (Bouchard \& McGue 2003) and recent work that has also established the heritability of political participation and predispositions (Fowler, Baker \& Dawes 2008, Klemmensen et al. 2012), suggest a causal relationship may go from genes to psychological traits to political predispositions and political participation. ${ }^{8}$ However, as has been suggested by Verhulst, Eaves \& Hatemi (2012) for political attitudes and personality traits, the underlying relationships may be more complicated.

\footnotetext{
${ }^{8}$ In addition to twin studies, recent work has used molecular genetic data to estimate the heritability of cognitive ability and personality traits (Davies et al. 2011, Vinkhuyzen et al. 2012). Also, studies have identified specific variants associated with both (Deary, Johnson \& Houlihan 2009, de Moor et al. 2012), however it is important that these associations are adequately replicated (Chabris et al. 2012).
} 


\section{Sample and Measures ${ }^{9}$}

The Swedish Twin Registry (STR) began in the 1950s and contains nearly all twins born in Sweden between 1886 and 2000 totaling more than 170,000 twins (Lichtenstein et al. 2006). The STR routinely administers surveys to its members and this article uses data from a recently administered survey called Screening Across the Life-span Twin study, Younger cohort (SALTY). ${ }^{10}$ The SALTY study was initiated in 2007 by a group of researchers in epidemiology, medicine, economics, and political science.

Beginning in early 2009, the survey was sent out to 24,914 Swedish twins born between 1943 and 1958 and the final reminders were sent out in the spring of 2010. The survey generated a total of 11,578 responses. Of these, 11,261 (97.2\%) respondents gave informed consent to have their responses stored and analyzed. Subject zygosity was classified either by questionnaire items with high reliability or, when available, by analysis of biosamples (Lichtenstein et al. 2006). In total, our sample is comprised of 2,346 complete same-sex twin pairs. In the Online Appendix Table 1, we report a comparison of respondents to non-respondents on a number of background characteristics. ${ }^{11}$ As is common in twin research, there is some oversampling of women. Respondents are also better educated and earn more money than non respondents. These differences, however, are quantitatively quite modest, never amounting to more than 0.2 standard deviations.

The SALTY survey collected detailed questions about political attitudes, predispositions,

\footnotetext{
${ }^{9}$ The data used in this study belongs to the Swedish Twin Registry. To obtain the data from the Swedish Twin Registry researchers must obtain approval from the Swedish Ethical Review Board and from the Steering Committee of the Swedish Twin Registry. Researchers using the data are required to follow the terms of an Assistance Agreement containing a number of clauses designed to ensure protection of privacy and compliance with relevant laws. For further information, contact patrik.magnusson@ki.se.

${ }^{10}$ Twins in the Swedish Twin Registry with a date of birth between January 1, 1943 and December 13, 1958 were sent the SALTY survey, provided at least one member of each twin pair had previously participated in a major phone survey administered by the registry.

${ }^{11}$ This data is for respondents and non-respondents from same-sex twin pairs.
} 
and behaviors from a genetically informative sample. In this article we focus on political predispositions and acts of participation. The acts are whether respondents reported voting in the 2006 Swedish parliamentary election, voting in the 2009 European Union election, and whether they have performed any of the following in the previous five years in order to express their political opinions: contacted a politician, contacted a public sector official, participated in a protest or demonstration, boycotted a certain good, made a financial contribution, and/or signed a petition. The eight acts of participation are summed to create a participation index ranging from $0-8 .{ }^{12}$

In terms of political predispositions, we asked subjects how interested they were in politics, questions gauging internal and external efficacy, how confident they were in Swedish politicians, and whether they viewed the act of voting as a civic duty. The questions about contacting officials, protesting, boycotting, making financial contributions, signing a petition, civic duty, internal efficacy, and external efficacy are taken from the Swedish Citizenship Survey (Petersson, Westholm \& Blomberg 1989). The questions about voting in the Swedish and EU parliamentary elections, interest in politics, and confidence in politicians are taken from the Swedish Election Study. ${ }^{13}$

As part of SALTY, we also administered batteries designed to measure personal control and extraversion. In order to measure personal control, we used the Locus of Control Scale (LOC) battery (Rotter 1966). ${ }^{14}$ The LOC classifies individuals along a single dimension capturing the degree to which they feel like they control the outcome of events. Individuals with an internal locus of control feel they control their own destiny and believe outcomes they realize are the product

\footnotetext{
${ }^{12}$ A Cronbach test of internal consistency is 0.59, similar to those reported by Fowler, Baker \& Dawes (2008) and Verba, Schlozman \& Brady (1995) ( $\alpha=0.61$ and $\alpha=0.62$ respectively).

${ }^{13}$ Exact question wording is reported in the Online Appendix

${ }^{14}$ The Rotter (1966) battery is made up of 13 questions, one of which that asked about student testing was not included on the survey due to the age of the sample. Two other questions were explicitly political in nature so we excluded them from our analysis. Therefore, our LOC score is based on 10 questions and thus ranges from 0-10.
} 
of their own effort and skills. Those with an external locus of control believe that outcomes are outside of their control. A low score on the scale is associated with an internal locus of control and a high score with an external locus of control. External control is also strongly related to neuroticism and internal control with self-efficacy (Judge et al. 2002). We reverse-coded the LOC so that higher scores are associated with higher internal locus of control. To measure extraversion, the survey included the 16 item Adult Measure of Behavioral Inhibition (AMBI) battery (Gladstone \& Parker 2005). The AMBI is a subjective measure of general long-standing inhibition designed to capture how an individual responds to social novelty and risk stimuli (Gladstone \& Parker 2005). Higher scores on the AMBI reflect a proneness for social avoidance and introversion. ${ }^{15}$ We reversecoded the AMBI so that higher scores are associated with extraversion.

Finally, we used social security numbers to match the men in the SALTY sample to conscription data provided by the Military Archives of Sweden. All men in our sample were required by law to participate in military conscription around the age of 18 . They enlisted at a point in time when exemptions from military duty were rare and typically only granted to men who could document a serious handicap that would make it impossible to complete training. Indeed, in our sample, we were able to successfully match $95 \%$ male twins to the information in the military archives. For the men born after 1950, approximately half of our sample, the military data has been digitalized. For the remaining twins, we manually retrieved the information from the Military Archives. The first test of cognitive ability used by the Swedish Military was implemented in 1944, and it has subsequently been revised and improved on a few occasions. Carlstedt (2000) discusses the history of psychometric testing in the Swedish military and provides evidence that the measure

\footnotetext{
${ }^{15}$ The correlation between AMBI and the Extraversion-Introversion scale from the Eysenck Personality Questionnaire-Revised (EPQ-R) is 0.75 (Gladstone \& Parker 2005).
} 
of cognitive ability is a good measure of general intelligence (Spearman 1904).

During the study period considered in this paper the cognitive ability test consisted of four subtests: logical, verbal, spatial and technical. The first subtest about logical ability was called "Instructions" and measured the ability to understand complicated instructions (the test had a raw score of 0-40). The second subtest about verbal ability was called "Selection" and in these questions the subjects had to pick out one out of five words that differed from the four other words (the test had a raw score of $0-40)$. The third test was a test of spatial ability called "Composition", where the subjects had to see which pieces fit with a specific figure (the test had a raw score of 0-25). The final test was called "Technical comprehension" and here the subjects answered questions about technical problems with the guidance of graphs (the test had a raw score of 0-52). To construct our measure of cognitive ability we summed the raw test scores for the 4 subtests. We then transformed the subjects summed test scores to the percentile rank in that birth year (using a standardization sample of all twins for whom cognitive ability data from the military archives was available, not just the SALTY respondents). This transformation ensures that there is no trend in cognitive ability over time in the data.

Since our measures of political predispositions and participation are all ordinal, we have transformed cognitive ability, personal control, and extraversion into deciles. Online Appendix Table 2 includes summary statistics for each of these variables broken out by zygosity. We expect cognitive ability, personal control, and extraversion to be positively related to both political predispositions and participation. 


\section{Biometric Modeling}

The process we follow for analyzing the SALTY data is in two steps. In the first step, we estimate how much of the variation in acts of participation and predispositions can be attributed to genetic and environmental factors. In the second step, we estimate the amount of genetic and environmental variation political behaviors and predispositions share with psychological traits. This is achieved by using a bivariate twin model.

\section{Univariate ACE Model}

The power of the classic twin design is that it leverages the fact that monozygotic (MZ) twins share $100 \%$ of their genes while dizygotic (DZ) twins share on average $50 \%$ of their genes. If we are willing to assume that differences in MZ and DZ twins for a particular trait are not due to similarity in the exogenous environmental conditions facing MZ twins, known as the equal environments assumption (EEA), we can then compare the similarity for that trait among MZ twin pairs to that of DZ twin pairs in order to get an estimate of the degree to which genes influence that trait. However, a violation of the EEA leads to an upward bias in heritability and a downward bias in common environment estimates. This bias may result in underestimating the common environmental correlation and overestimating the genetic correlation between two traits in the bivariate analysis (described below). Several recent studies attempting to test for upward bias in the heritability of political attitudes have failed to find evidence of an EEA violation (Hatemi et al. 2009a, Hatemi et al. 2010, Smith et al. 2012, Littvay 2012). However, scholars continue to criticize the use of the classic twin design to study political traits (Shultziner 2013). ${ }^{16}$

\footnotetext{
${ }^{16} \mathrm{~A}$ more detailed discussion of the EEA is contained in the Online Appendix.
} 
More formally, the classical twin model assumes that the variance in observed behavior can be partitioned into additive genetic factors (A), and environmental factors which are shared or common to co-twins (C), and unique environmental factors (E). This is the so-called ACE model. ${ }^{17}$ Common environment includes the family environment in which both twins were raised and any other factor to which both twins were equally exposed. In contrast, the unique environment includes influences that are experienced individually. The role of genes and environment are not measured directly but their influence is inferred via their effects on the covariances of twin siblings (Neale \& Cardon 1992). ${ }^{18}$

Since the variables we focus on in this study are ordinal, we estimate a threshold model that assumes a continuous latent distribution underlying a given trait for which we observe thresholds demarcating categories. The thresholds are typically constrained to be the same for both members of the twin pair as well as for MZ and DZ twins, both of which we do here. However, we estimate different thresholds for males and females in all of the models. ${ }^{19}$ The variance components as well as the thresholds are estimated via maximum likelihood.

\section{Bivariate ACE Model}

In order to estimate how much of the covariation between political behaviors and psychological traits can be attributed to the same genetic source, we must move from a univariate to a bivariate model. We use a Cholesky decomposition model (Martin \& Eaves 1977) that assumes that the latent factors underlying a first trait also influence a second trait but the latent factors underlying

\footnotetext{
${ }^{17}$ For a primer of biometric modeling geared for political scientists see Medland \& Hatemi (2009).

${ }^{18} \mathrm{~A}$ more detailed description of the univariate model is presented in the Online Appendix.

${ }^{19}$ We ran sex limitation models which assume sex-specific variance components. In each case we could not statistically reject a pooled model in favor of a sex limitation model. Model fit statistics for the pooled and sex limitation models are resorted in Online Appendix Table 3. Estimates from both models are presented in Online Appendix Table 4. Based on the univariate results we only estimate pooled bivariate models.
} 
the second trait do not affect the first trait. ${ }^{20}$ The Cholesky model, as developed here, assumes a recursive ordering where genes influence a psychological trait and then the psychological trait influences the political variable, subject to a disturbance which has the familiar ACE structure. This recursive structure is of course incorrect if personality is not causally antecedent to political behavior. An alternative approach is to allow each variance component of the first trait to be correlated with the corresponding variance component in the second trait. Loehlin (1996) shows how the parameter estimates from such a model are readily transformed into the parameters from our recursive model since both models span the same model parameter space. ${ }^{21}$ In addition, this model assumes that the latent genetic and environmental factors underlying the two traits are uncorrelated with one another across and within individuals. These assumptions are necessary in order for the model to be identified and leaves us with nine parameters to be estimated. Since both variables in our bivariate models are ordinal, estimation of the thresholds and variance components is achieved following the same approach described in the univariate case.

The parameter estimates generated by this bivariate model can be used to construct quantities of interest. The genetic correlation quantifies the degree to which the genetic endowment of two traits covary. ${ }^{22}$ A correlation of 0 means that the two traits are influenced by completely different genes and a correlation of 1 means the same genes influence both traits. Another meaningful quantity is the percentage of the covariation between two traits that can be explained by additive genetic factors. ${ }^{23}$

\footnotetext{
${ }^{20} \mathrm{~A}$ more detailed description of the bivariate model is presented in the Online Appendix.

${ }^{21}$ The proof of this is straightforward and consists of merely writing the variance-covariance matrices of the two models in terms of the underlying structural parameters and equating the elements from matrix 1 with the corresponding elements from matrix 2 .

${ }^{22}$ We denote the genetic correlation as $r_{g}$, the common environment correlation as $r_{c}$, and the unique environment correlation as $r_{e}$.

${ }^{23}$ The genetic correlation, without incorporating the extent to which the two traits are heritable, only tells part
} 


\section{Univariate Results}

The estimates of heritability, common environment, and unique environment for self-reported vote in the 2006 Swedish parliamentary election and 2009 European Union election are presented in Table $1 .^{24}$ We also show estimates for other acts of participation including contacting a politician, contacting a public sector official, participating in a protest or demonstration, boycotting a certain good, making a financial contribution, and signing a petition.

The heritability estimates for three of the acts are significantly different from zero. In particular, the heritability for voting in the Swedish parliamentary election is close to the estimates reported by Fowler, Baker \& Dawes (2008), however it should be noted that there is very little variation in our measure since $96 \%$ of the sample reported voting. Therefore, we urge caution in interpreting the univariate and bivariate results for voting in parliamentary election. ${ }^{25}$ The heritability estimate for the sum of self-reported activities is a bit lower than the participation index reported by Fowler, Baker \& Dawes (2008), however it is very close to the estimates reported by Klemmensen et al. (2012) based on US and Danish samples. While not statistically different from zero in the ACE model, heritability estimates for protesting, participating in a boycott, and making financial contributions to candidates or parties are similar in magnitude. Like voting in the EU election, signing a petition yields a heritability estimate that is small and about the same size as the estimate for common environment. The point estimates for common environment are at or near zero for contacting a politician, contacting an elected official, voting in the Swedish parliamentary, and the overall index and are insignificant for every act of participation, suggesting

of the story. For example, the same genes may be influencing two traits, but these genes may not account for very much of the variation in each of the traits.

${ }^{24}$ All results reported are based on complete twin pairs.

${ }^{25}$ Overall turnout in Sweden was $90 \%$ in the age group we study. 
the common environment plays at best a small role in these outcomes.

The univariate results for political interest, internal and external political efficacy, confidence in politicians, and civic duty are also presented in Table 1. The heritability estimates are significantly different from zero and the percentage of the variation accounted for by common environment is insignificant for all five variables. The heritability estimates for most of the variables are moderate in magnitude, however genetic factors account for approximately half of the variation in interest in politics.

Our estimate for political efficacy is similar to those reported by Klemmensen et al. (2012) and our estimate for civic duty is similar to Loewen \& Dawes (2012). ${ }^{26}$ Confidence in politicians has never been studied in a behavioral genetic context. These results suggest that genetic variation influences a wide variety of political behaviors and predispositions that are thought to influence political participation.

\section{Bivariate Results}

The purpose of the second step of our analysis is to quantify the amount of the covariation between acts of participation and psychological traits that can be attributed to a common genetic source. As a starting point, Table 2 presents the polychoric correlations between each trait we found to be heritable and personal control, extraversion, and cognitive ability. The correlations are relatively moderate (ranging from 0.09 to 0.32 in absolute value) but they are significant, suggesting that each of these psychological characteristics plays a role in explaining several different acts of political engagement.

\footnotetext{
${ }^{26}$ Klemmensen et al. (2012) did not find significant heritable variation in civic duty based on a Danish sample.
} 
Based on the results from the univariate model, we restrict the bivariate analysis of personal control and extraversion to acts for which we found a heritability estimate statistically distinguishable from zero (voting in the Swedish parliamentary election, contacting a politician, contacting a public sector official, and the overall index). For cognitive ability, we restrict the analysis to acts for which heritability estimates are statistically distinguishable from zero for men (contacting a politician and contacting a public sector official) since we only have a measure of cognitive ability for males in the sample. Additionally, since the common environment point estimates for these acts of participation and psychological traits are at or close to zero and insignificant in the univariate model, we estimate a model assuming that the common environment correlation is zero. However, while dropping insignificant parameters from the model is common practice in behavioral genetics, it is not without its critics (Goldberger 2002) because the reported p-values do not reflect the model selection procedure. Therefore, we also present the results for the unrestricted models in the Online Appendix. ${ }^{27}$

The genetic and environmental correlations for the three acts of political participation as well as the overall index and the the percentage of the total correlation due to genetic and environmental factors are presented in Table $3 .^{28}$ The only insignificant genetic correlation is between turnout and personal control. Of the acts for which the genetic correlations were significant, genetic factors make up between $65 \%$ and $97 \%$ of the total correlation. These results suggest that for contacting politicians and public sector officials, common genes account for nearly all of the correlation with the three psychological traits. There is also evidence of genetic overlap for the

\footnotetext{
${ }^{27}$ Fit statistics comparing the restricted and unrestricted models are presented in Online Appendix Table 5 and estimates from the unrestricted model are presented in Online Appendix 6 and Online Appendix \%. In all cases the common environment correlation is insignificant in the full model.

${ }^{28}$ The percentages are graphically illustrated in Online Appendix Figure 3.
} 
index of overall participation and both personal control and extraversion. The results for turnout are not as strong likely due to the limited variation in the measure.

The genetic and environmental correlations for all of the political predispositions and the percentage of the total correlation due to genetic and environmental factors are also presented in $T a$ ble $3 .^{29}$ All of the genetic correlations between political predispositions and the psychological traits are significant and genetic factors account for between $49 \%$ and $100 \%$ of the total correlation. ${ }^{30}$

Our results add a new dimension to the behavior literature. Verba, Schlozman \& Brady (1995) classify contacting officials as a skill-based act because it requires individuals to be organized and write and speak effectively, skills that are correlated with cognitive ability. Competence theory holds that individuals who believe that they will achieve a desired policy goal by contacting an official will be more likely to do so. Mondak et al. (2010) report a strong positive relationship between extraversion and contacting a member of the US congress. Also, previous research has demonstrated that personal control is linked with political efficacy (Guyton 1988, Cohen, Vigoda \& Samorly 2001) and civic duty (Blais \& St-Vincent 2011); extraversion to political efficacy (Vecchione \& Caprara 2009, Blais \& St-Vincent 2011, Mondak \& Halperin 2008), interest in politics (Blais \& St-Vincent 2011) and civic duty (Blais \& St-Vincent 2011); and cognitive ability to interest in politics (Verba, Schlozman \& Brady 1995) and political efficacy (Verba, Schlozman \& Brady 1995). We demonstrate that most of these relationships can be explained by variation in the same set of genes.

The question is how to interpret these results. Most scholars studying the relationship

\footnotetext{
${ }^{29}$ The percentages are graphically illustrated in Online Appendix Figure 4.

${ }^{30}$ The genetic correlations for cognitive ability and several of the predispositions are over $100 \%$ because the unique environmental correlations are negative. However, all of these environmental correlations are not significantly different from zero.
} 
between psychological and political traits have at least implicitly assumed that political traits are causally influenced by personality and cognitive ability. This implies genes would exert an indirect influence on political participation via psychological traits. Alternatively, if the same set of genes influence psychological traits and political participation separately, then the observed relationship between the two may be at least in part confounded by genetic factors.

\section{Direction of Causation}

The Choleksy bivariate model does not provide information about the causal relationship between genes, psychological traits, and political participation (Posthuma et al. 2003). However, behavioral genetics scholars have developed the Direction of Causation (DoC) model which attempts to test empirically the potential causal pathways (Heath et al. 1993, Duffy \& Martin 1994). The DoC model has recently been employed by Verhulst, Eaves \& Hatemi (2012) to study the relationship between personality and political attitudes.

The DoC model takes advantage of genetic relationships among family members to study, based on cross-sectional data, hypothesized casual relationships between two traits. The model tests three scenarios: a unidirectional causal influence of Trait A on Trait B, a unidirectional influence of Trait B on Trait A, and reciprocal causation. The DoC model evaluates expected cross-twin cross-trait covariances given possible causal relationships. If Traits A and Trait B have different modes of inheritance, for instance Trait A is best explained by common environmental and unique environmental factors whereas Trait B is best explained by additive genetic and unique environmental factors, then the cross-twin cross-trait covariance expected given A causes B would be different than if B causes A. More specifically, in the case of the former, the cross-twin cross- 
trait covariance would be proportional to the common environmental component of Trait A and in the case of the latter the cross-twin cross-trait covariance would be proportional to the genetic component of Trait B. In the case of reciprocal causation, the cross-twin cross-trait covariance would be a combination of the common environment component of Trait A and the genetic component of Trait B. ${ }^{31}$ Since all three cases of the DoC model are nested within the Choleksy model (Heath et al. 1993), they can be compared to the Cholesky using a likelihood ratio test to suggest the most appropriate causal relationship based on the data.

We estimate the three DoC models (two unidirectional and reciprocal causation) for each of the three psychological traits and the political activity index as well as the measures of political dispositions. ${ }^{32}$ The model fit information is presented in Online Appendix Table 8. The DoC analysis cannot reject the Cholesky as the best fitting model for all of the political predispositions and both extraversion and personal control. The best fitting model for the political activity index and extraversion is reciprocal causation and for the political activity index and personal control is reverse causality. The best fitting model suggests a causal relationship running from cognitive ability to the overall measure of political activity, interest in politics, civic duty, and confidence in politicians. A reciprocal causation model fit best for the relationship between cognitive ability and internal efficacy, and external efficacy. However, reverse causality is unlikely since cognitive ability was measured in adolescence while political efficacy was measured much later in life.

In summary, similar to what Verhulst, Eaves \& Hatemi (2012) report for political attitudes,

\footnotetext{
${ }^{31}$ This example is expanded upon in the Online Appendix. See Verhulst \& Estabrook (2012) for a detailed discussion of the DoC model intended for a political science audience.

${ }^{32}$ DoC are sensitive to measurement errors (Heath et al. 1993, Duffy \& Martin 1994, Gillespie et al. 2003). Therefore, we use test-retest correlations for each of the traits, based on 496 twins in the SALTY sample, to correct for measurement error in the DoC and Cholesky. In general, our estimation process is modeled after (Luciano et al. 2005). All measures are treated as continuous in our DoC analysis.
} 
our DoC results suggest a pleiotropic relationship between personality traits and political predispositions. We also found support for a mediation relationship between cognitive ability and political predispositions and participation. However, it is important to point out a major limitation of the DoC analysis. The power to detect the direction of causality is greatest when both traits have very different modes of inheritance (Heath et al. 1993, Duffy \& Martin 1994, Gillespie et al. 2003). It is clear from the univariate results presented in Table 1 that all of the political and psychological traits we study are best explained by an additive genetic and unique environmental component. As a result, the cross-twin cross-trait covariances will be very similar under the two unidirectional hypotheses and therefore large samples are required to achieve adequate power necessary to distinguish between the two directional hypotheses (Gillespie et al. 2003).

\section{Discussion}

The SALTY sample is unique in a number of ways. It is one of the first studies to ask a very large sample of twins an extensive battery of questions about engagement in well-studied political activities as well as predispositions towards politics. Our sample also contains measures of psychological traits allowing us to explore the conjecture that genes influence political participation indirectly through these traits. And since cognitive ability was measured in adolescence while political variables were measured later in life, it suggests that the causal arrow flows from cognitive ability to politics and not the other way around.

Based on our univariate modeling, we find that the total number of self-reported participatory acts is heritable, as are specific acts like contacting a politician or a public sector employee. These heritabilities range from 0.36 to 0.52 , similar to what has been found for other political be- 
haviors (Fowler, Baker \& Dawes 2008, Klemmensen et al. 2012). We find mixed results for turnout, however the confidence intervals for voting in the Swedish and EU elections overlap suggesting the two estimates cannot be distinguished from one another statistically. On the other hand, we fail to find significant heritability for participating in a protest, boycotting, making a financial contribution, or signing a petition. The fact that the total number of acts is heritable, combined with similar magnitudes for the heritability estimates for protesting, boycotting, and making contributions, suggests that genetic variation explains individual differences in overall political participation.

For political predispositions, heritability estimates were significant for political interest, internal and external political efficacy, confidence in politicians, and the view that voting is a civic duty. These estimates range from 0.24 to 0.50 in line with other recent studies (Klemmensen et al. 2012). The magnitudes for these estimates are also quite similar to what we found for acts of participation. Our result that $50 \%$ of the variation in political interest can be attributable to genetic factors potentially has implications for the finding by Prior (2010) that people tend to be either interested or uninterested in politics and that this predisposition is exceptionally stable over the life cycle. The determinants of political interest are not currently well known, however the observed relationship may be due in part to genetic variation in the population.

These results are very similar to those based on samples in the US as well as Sweden's neighbor Denmark suggesting that our findings may be informative about the heritability of political participation and predispositions in other modern Western democracies. However, it is important to point out that our heritability estimates, like any other descriptive statistic, are specific to the time and population on which they are based. ${ }^{33}$ Therefore, we urge caution when extrapolating

\footnotetext{
${ }^{33}$ For a more detailed discussion of the concept of heritability, see Hatemi et al. (2009b) and Hatemi, Byrne \& McDermott (2012).
} 
to other societies and eras. The relative importance of genes crucially depends on the prevailing cultural and institutional setting.

Our bivariate results for political participation show that genetic factors account for $65 \%$ to $88 \%$ of the correlation between extraversion and the three acts of participation we examined as well as the overall number of reported acts. In addition, personal control significantly overlaps with contacting a politician and contacting a public sector official, with genetic factors accounting for $92 \%$ and $81 \%$ of the total correlation. For political predispositions, all of the genetic correlations are significant and account for between $49 \%$ and $100 \%$ of the total correlation. These results thus present evidence that most of the relationship between psychological traits and political participation can be explained by the same set of genes. In this light, we view the work presented here as an important step in a research agenda aimed at better understanding the role that variation in genetic endowments for personality, skills, traits and preferences plays in generating heritable variation in political behavior. The theoretical argument made by Mondak (2010) suggest that a significant genetic correlation should be interpreted as evidence of mediation, however since the Cholesky model cannot establish mediation our estimates should be only thought of as an upper bound on the proportion of the heritable variation in political traits that may be mediated by the psychological traits we study.

Overall, genes account for the lion's share of the overlap between the psychological traits and political behaviors we focus on, but the size of this overlap is relatively modest. Figure 1 illustrates this by putting the percentages in terms of the correlations between psychological and political traits (all presented in Table 3). For example, nearly all of the correlation between cognitive ability and contacting a politician can be attributed to genetic factors. However, since the total correlation 
is 0.25 it implies that the influence of extraversion can only account for $6 \%$ of the variation in contacting a politician. If our results are viewed as evidence of mediation, the remaining $46 \%$ of the variation in contacting a politician explained by genetic factors is not mediated by cognitive ability. Therefore, our findings suggest that future work must consider other potential mediators.

\section{Limitations}

There are several limitations to our study. Though we have applied standard methodology, it is well known that the assumptions needed to identify an ACE model are quite strong, especially the equal environments assumption. As we stated earlier, a violation of the EEA leads to an upward bias in heritability and a downward bias in common environment estimates. We suggest that future work use samples incorporating other sibling types and pedigrees to evaluate some of the moment restrictions assumptions in the ACE model. New analytical tools have also recently been developed that rely on direct measures of genetic relatedness, and thus do not rely on the EEA, to estimate heritability (Yang et al. 2010, Yang et al. 2011, Visscher, Yang \& Goddard 2010).

Another limitation is that we have only studied bivariate relationships, but in future work we will examine more complicated pathways linking genes, psychological traits, political predispositions, and political participation. In addition, several of the relationships between political and psychological traits are small in magnitude making it difficult to decompose their covariance without a very large sample. Therefore, our results for trait pairs with correlations smaller than 0.2 can only be considered suggestive at this point.

Finally, based on recent work discussed earlier, we argue that our results raise the possibility that psychological traits mediate the relationship between genes and political participation. We 
attempted to test this assertion by estimating a Direction of Causation but unfortunately power limitations due to the similar inheritance pattern exhibited by all of the traits we study likely limit our ability to distinguish between possible relationships (Heath et al. 1993, Duffy \& Martin 1994). However, more adequately powered studies should revisit this question in the future. 


\section{Tables}

\begin{tabular}{|c|c|c|c|}
\hline & Heritability & $\begin{array}{c}\text { Common } \\
\text { Environment }\end{array}$ & $\begin{array}{c}\text { Unique } \\
\text { Environment }\end{array}$ \\
\hline \multirow[t]{2}{*}{ Vote (Parliament) } & 0.41 & 0.00 & 0.59 \\
\hline & {$[0.03,0.58]$} & {$[0.00,0.29]$} & {$[0.42,0.79]$} \\
\hline \multirow[t]{2}{*}{ Vote (EU) } & 0.17 & 0.19 & 0.64 \\
\hline & {$[0.00,0.43]$} & {$[0.00,0.36]$} & {$[0.55,0.73]$} \\
\hline \multirow[t]{2}{*}{ Contact Politician } & 0.52 & 0.00 & 0.48 \\
\hline & {$[0.31,0.63]$} & {$[0.00,0.15]$} & {$[0.37,0.61]$} \\
\hline \multirow[t]{2}{*}{ Contact Official } & 0.41 & 0.00 & 0.59 \\
\hline & {$[0.15,0.53]$} & {$[0.00,0.20]$} & {$[0.47,0.72]$} \\
\hline \multirow[t]{2}{*}{ Attend Protest } & 0.35 & 0.11 & 0.55 \\
\hline & {$[0.00,0.61]$} & {$[0.00,0.44]$} & {$[0.39,0.73]$} \\
\hline \multirow[t]{2}{*}{ Boycott Participation } & 0.29 & 0.08 & 0.63 \\
\hline & {$[0.00,0.49]$} & {$[0.00,0.33]$} & {$[0.51,0.76]$} \\
\hline \multirow[t]{2}{*}{ Financial Contributions } & 0.44 & 0.04 & 0.52 \\
\hline & {$[0.00,0.65]$} & {$[0.00,0.41]$} & {$[0.35,0.74]$} \\
\hline \multirow[t]{2}{*}{ Sign a Petition } & 0.15 & 0.16 & 0.69 \\
\hline & {$[0.00,0.39]$} & {$[0.00,0.32]$} & {$[0.60,0.78]$} \\
\hline \multirow[t]{2}{*}{ Participation Index (0-8) } & 0.36 & 0.05 & 0.59 \\
\hline & {$[0.20,0.46]$} & {$[0.00,0.18]$} & {$[0.54,0.64]$} \\
\hline \multirow[t]{2}{*}{ Interest in Politics } & 0.50 & 0.06 & 0.44 \\
\hline & {$[0.35,0.61]$} & {$[0.00,0.19]$} & {$[0.39,0.49]$} \\
\hline \multirow[t]{2}{*}{ Internal Efficacy } & 0.36 & 0.00 & 0.64 \\
\hline & {$[0.23,0.41]$} & {$[0.00,0.09]$} & {$[0.59,0.70]$} \\
\hline \multirow[t]{2}{*}{ External Efficacy } & 0.24 & 0.10 & 0.66 \\
\hline & {$[0.08,0.39]$} & {$[0.00,0.22]$} & {$[0.61,0.72]$} \\
\hline \multirow[t]{2}{*}{ Civic Duty } & 0.29 & 0.05 & 0.67 \\
\hline & {$[0.12,0.39]$} & {$[0.00,0.18]$} & {$[0.61,0.73]$} \\
\hline \multirow[t]{2}{*}{ Confidence in Politicians } & 0.37 & 0.06 & 0.57 \\
\hline & {$[0.19,0.49]$} & {$[0.00,0.20]$} & {$[0.51,0.63]$} \\
\hline \multirow[t]{2}{*}{ Personal Control } & 0.24 & 0.00 & 0.76 \\
\hline & {$[0.10,0.29]$} & {$[0.00,0.11]$} & {$[0.71,0.82]$} \\
\hline \multirow[t]{2}{*}{ Extraversion } & 0.45 & 0.00 & 0.55 \\
\hline & {$[0.38,0.49]$} & {$[0.00,0.05]$} & {$[0.51,0.60]$} \\
\hline \multirow[t]{2}{*}{ Cognitive Ability (Males) } & 0.67 & 0.12 & 0.21 \\
\hline & {$[0.51,0.81]$} & {$[0.00,0.26]$} & {$[0.18,0.25]$} \\
\hline
\end{tabular}

Table 1: Heritability Estimates for Psychological and Political Traits. Parameter estimates and 95\% confidence intervals in brackets are shown for a univariate ACE model that allows different thresholds for males and females. 


\begin{tabular}{lccc}
\hline \hline & $\begin{array}{c}\text { Personal } \\
\text { Control }\end{array}$ & Extraversion & $\begin{array}{c}\text { Cognitive } \\
\text { Ability (Males) }\end{array}$ \\
\hline Vote (Parliament) & 0.12 & 0.18 & 0.19 \\
& {$[0.04]$} & {$[0.03]$} & {$[0.06]$} \\
Contact Politician & 0.10 & 0.22 & 0.25 \\
& {$[0.03]$} & {$[0.03]$} & {$[0.04]$} \\
Contact Official & 0.11 & 0.22 & 0.18 \\
& {$[0.03]$} & {$[0.03]$} & {$[0.04]$} \\
Participation Index $(0-8)$ & 0.09 & 0.19 & 0.24 \\
& {$[0.02]$} & {$[0.02]$} & {$[0.02]$} \\
\hline Interest in Politics & 0.17 & 0.22 & 0.20 \\
& {$[0.02]$} & {$[0.01]$} & {$[0.02]$} \\
Internal Efficacy & 0.22 & 0.27 & 0.28 \\
& {$[0.02]$} & {$[0.01]$} & {$[0.02]$} \\
External Efficacy & 0.21 & 0.22 & 0.32 \\
& {$[0.02]$} & {$[0.02]$} & {$[0.02]$} \\
Voting is a Civic Duty & 0.11 & 0.14 & 0.09 \\
& {$[0.02]$} & {$[0.02]$} & {$[0.02]$} \\
Confidence in Politicians & 0.22 & 0.17 & 0.24 \\
& {$[0.02]$} & {$[0.02]$} & {$[0.03]$} \\
\hline \hline
\end{tabular}

Table 2: Relationship Between Political Traits and Psychological Traits. Correlation coefficients and standard errors in brackets are shown. 


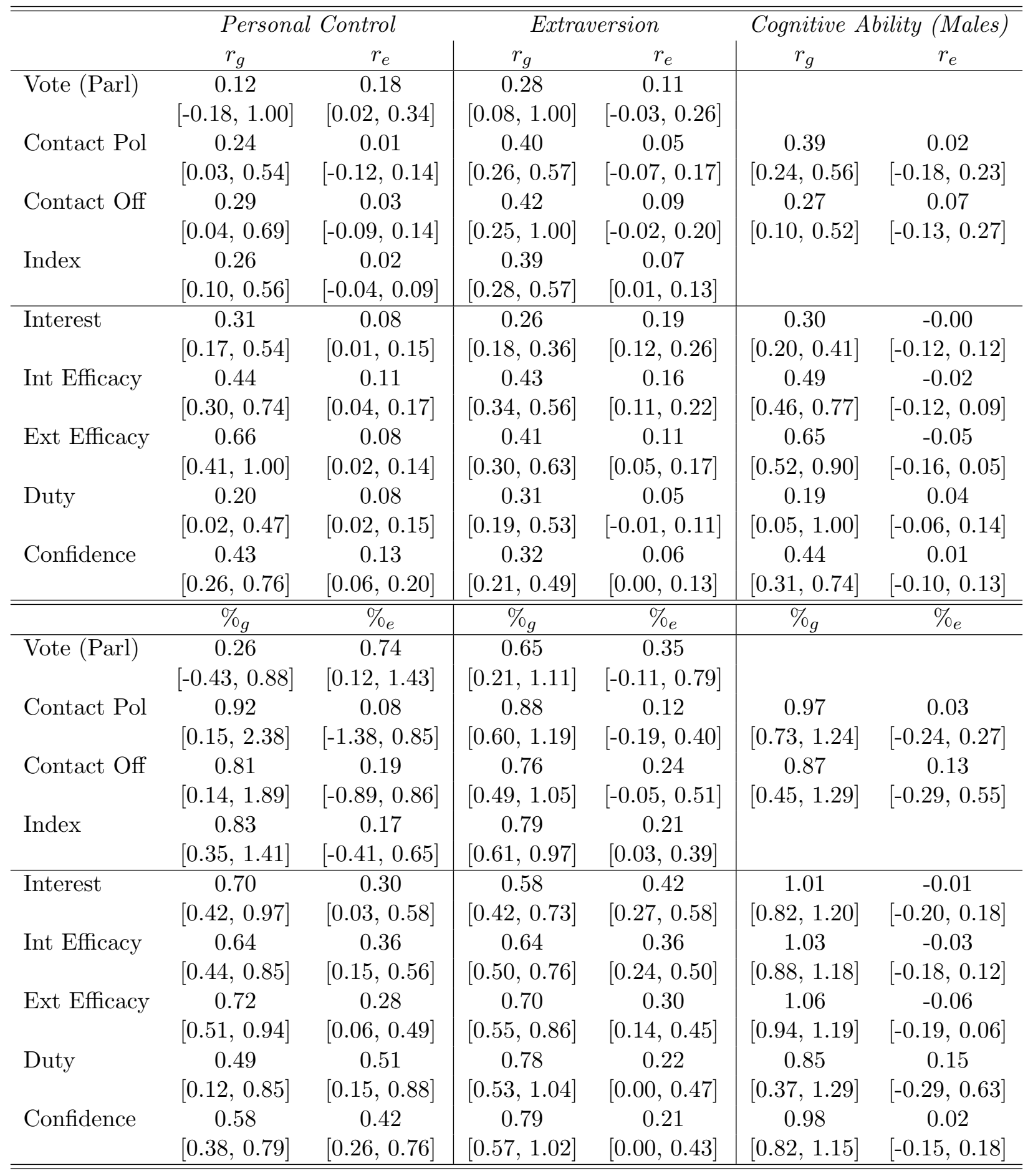

Table 3: Top panel: Genetic and Environmental Correlation and 95\% CIs from a Bivariate Cholesky ACE models of Personal Control, Extraversion, and Cognitive Ability with Political Traits. Bottom panel: Percentage of total correlation due to Genetic and Unique Environmental factors and 95\% CIs. 


\section{Figures}
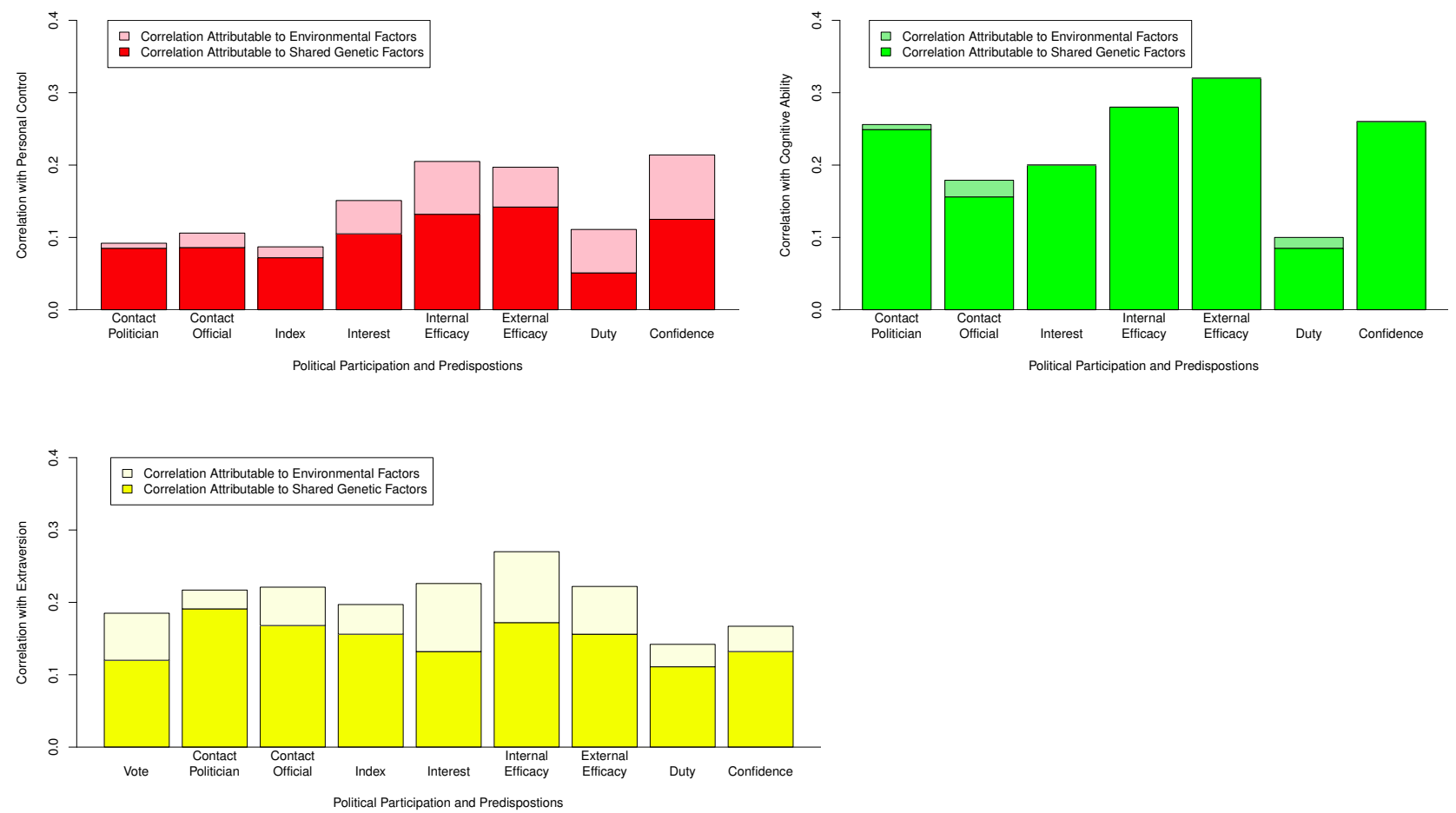

Figure 1: Correlations between psychological and political traits. The overall height of the bar is the total correlation, the dark portion is the genetic component, and the light portion is environmental component. 


\section{References}

Adorno, T.W., E. Frenkel-Brunswik, D.J. Levinson \& R.N. Sanford. 1950. The Authoritarian Personality. Harpers.

Alford, J., C. Funk \& J. Hibbing. 2005. "Are Political Orientations Genetically Transmitted?" American Political Science Review 99(2):153-167.

Arceneaux, Kevin, Martine Johnson \& Hermine H Maes. 2012. "The genetic basis of political sophistication." Twin Res Hum Genet 15(1):34-41.

Benjamin, D., S. Brown \& J. Shapiro. 2006. "Who is Behavioral?" Unpublished Manuscript.

Blais, A. \& S.L. St-Vincent. 2011. "Personality traits, political attitudes and the propensity to vote." European Journal of Political Research 50(3):395-417.

Bono, J. \& T. Judge. 2003. "Core Self-Evaluations: A Review of the Trait and its Role in Job Satisfaction and Job Performance." European Journal of Personality 17:S5-18.

Bouchard, T. \& M. McGue. 2003. "Genetic and Environmental Influences on Human Psychological Differences." Journal of Neurobiology 54(1):4-45.

Campbell, A., P. Converse, W. Miller \& D. Stokes. 1960. The American Voter. University of Chicago Press.

Carlson, J. \& M. Hyde. 1980. "Personality and Political Recruitment: Actualization or Compensation." Journal of Psychology 106(1):117-119.

Carlstedt, B. 2000. Cognitive Abilities: Aspects of Structure, Process, and Measurement PhD thesis Gothenburg University.

Carmines, E. 1980. A Competence Theory Versus Need Theory of Political Involvement. In Political Psychology: Readings in Research and Theory, ed. G. Kourvetaris. Transaction.

Chabris, C.F., B.M. Hebert, D.J. Benjamin, J. Beauchamp, D. Cesarini, M. van der Loos, M. Johannesson, P.K.E. Magnusson, P. Lichtenstein, C.S. Atwood et al. 2012. "Most reported ge- 
netic associations with general intelligence are probably false positives." Psychological Science

Cohen, A., E. Vigoda \& A. Samorly. 2001. "Analysis of the Mediating Effect of PersonalPsychological Variables on the Relationship Between Socioeconomic Status and Political Participation: A Structural Equations Framework." Political Psychology 22(4):727-757.

Davies, G, A Tenesa, A Payton, J Yang, SE Harris, D Liewald, X Ke, S Le Hellard, A Christoforou, M Luciano, K McGhee, L Lopez, AJ Gow, J Corley, P Redmond, HC Fox, P Haggarty, LJ Whalley, G McNeill, ME Goddard, T Espeseth, AJ Lundervold, I Reinvang, A Pickles, VM Steen, W Ollier, DJ Porteous, M Horan, JM Starr, N Pendleton, PM Visscher \& IJ Deary. 2011. "Genome-wide association studies establish that human intelligence is highly heritable and polygenic." Molecular Psychiatry 16(10):996-1005.

de Moor, MH, PT Costa, A Terracciano, RF Krueger, EJ de Geus, T Toshiko, BW Penninx, T Esko, PA Madden, J Derringer, N Amin, G Willemsen, J-J Hottenga, MA Distel, M Uda, S Sanna, P Spinhoven, CA Hartman, P Sullivan, A Realo, J Allik, AC Heath, ML Pergadia, A Agrawal, P Lin, R Grucza, T Nutile, M Ciullo, D Rujescu, I Giegling, B Konte, E Widen, DL Cousminer, JG Eriksson, A Palotie, L Peltonen, M Luciano, A Tenesa, G Davies, LM Lopez, NK Hansell, SE Medland, L Ferrucci, D Schlessinger, GW Montgomery, MJ Wright, YS Aulchenko, AC Janssens, BA Oostra, A Metspalu, GR Abecasis, IJ Deary, K Räikkönen, LJ Bierut, NG Martin, CM van Duijn \& DI Boomsma. 2012. "Meta-analysis of genome-wide association studies for personality." Molecular Psychiatry 17:337-349.

Deary, I., D. Batty \& C. Gale. 2008. "Childhood Intelligence Predicts Voter Turnout, Voting Preferences, and Political Involvement in Adulthood: The 1970 British Cohort Study." Intelligence $36: 548-555$.

Deary, Ian J, W Johnson \& L M Houlihan. 2009. "Genetic foundations of human intelligence." Hum Genet 126(1):215-32.

Denny, K. \& O. Doyle. 2008. "Political Interest, Cognitive Ability and Personality: Determinants of Voter Turnout in Britain." British Journal of Political Science 38:291-310. 
Duffy, D L \& N G Martin. 1994. "Inferring the direction of causation in cross-sectional twin data: theoretical and empirical considerations." Genet Epidemiol 11(6):483-502.

Eysenck, H.J. 1954. The Psychology of Politics. Transaction Pub.

Fazekas, Zoltán \& Levente Littvay. 2012. "Choosing sides: The genetics of why we go with the loudest." Journal of Theoretical Politics 24(3):389-408.

URL: http://jtp.sagepub.com/cgi/content/abstract/24/3/389

Fowler, J. \& C. Kam. 2006. "Patience as a Political Virtue: Delayed Gratification and Turnout." Political Behavior 28:113-128.

Fowler, J. \& D. Schreiber. 2008. "Biology, Politics, and the Emerging Science of Human Nature." Science 322(5903):912-914.

Fowler, James H., Laura A. Baker \& Christopher T. Dawes. 2008. "Genetic Variation in Political Behavior." American Political Science Review 102(2):233-248.

Gallego, A. \& D. Oberski. 2012. "Personality and Political Participation: The Mediation Hypothesis." Political Behavior 34(3):425-451.

Gerber, A., G. Huber, D. Doherty, C. Dowling, C. Raso \& S. Ha. 2011. "Personality Traits and Participation in Political Processes." Journal of Politics 73(3):692-706.

Gillespie, Nathan A, Gu Zhu, Michael C Neale, Andrew C Heath \& Nicolas G Martin. 2003. "Direction of causation modeling between cross-sectional measures of parenting and psychological distress in female twins." Behav Genet 33(4):383-96.

Gladstone, G. \& G. Parker. 2005. "Measuring a Behaviorally Inhibited Temperament Style: Development and Initial Validation of New Self-Report Measures." Psychiatry Research 135:133-143.

Goldberger, A. 2002. "Structural Equation Models in Human Behavior Genetics." University of Wisconsin Social Systems Working Paper.

Guyton, E. 1988. "Critical Thinking and Political Participation: Development and Assessment of a Causal Model." Theory and Research in Social Education 16(23-49). 
Hatemi, P., C. Funk, S. Medland, H. Maes, J. Silberg, N. Martin \& L. Eaves. 2009a. "Genetic and Environmental Transmission of Political Attitudes Over the Life Time." Journal of Politics 71(3):1141-1156.

Hatemi, P., J. Hibbing, S. Medland, M. Keller, J. Alford, K. Smith, N. Martin \& L. Eaves. 2010. "Not by Twins Alone: Using Extended Family Design to Investigate Genetic Influence on Political Beliefs." American Journal of Political Science 54(3):798-814.

Hatemi, Peter K, Christopher T Dawes, Amanda Frost-Keller, Jaime E Settle \& Brad Verhulst. 2011. "Integrating social science and genetics: News from the political front." Biodemography and social biology 57(1):67-87.

Hatemi, Peter K., John Hibbing, John Alford, Nicholas Martin \& Lindon Eaves. 2009b. "Is There a Party in Your Genes." Political Research Quarterly 62(3):584-600.

Hatemi, Peter K \& Rose McDermott. 2012. "The genetics of politics: discovery, challenges, and progress." Trends Genet .

Hatemi, P.K., E. Byrne \& R. McDermott. 2012. "Introduction: What is a 'gene'and why does it matter for political science?" Journal of Theoretical Politics 24(3):305-327.

Hauser, S. 2000. "Education, Ability, and Civic Engagement in the Contemporary United States." Social Science Research 29:556-582.

Heath, A C, R C Kessler, M C Neale, J K Hewitt, L J Eaves \& K S Kendler. 1993. "Testing hypotheses about direction of causation using cross-sectional family data." Behav Genet $23(1): 29-50$.

Judge, T., A. Erez, J. Bono \& C. Thoresen. 2002. "Are Measures of Self-Esteem, Neuroticism, Locus of Control, and Generalized Self-Efficacy Indicators of a Common Core Construct?" Journal of Personality and Social Psychology 83(3):693-710.

Kirby, K., G. Winston \& Santiesteban. 2005. "Impatience and Grades: Delay-discount Rates Correlate Negatively with College GPA." Learning and Individual Differences 15(3):213-222. 
Klemmensen, Robert, Peter K Hatemi, Sara Binzer Hobolt, Inge Petersen, Axel Skytthe \& Asbjørn S Nørgaard. 2012. "The genetics of political participation, civic duty, and political efficacy across cultures: Denmark and the United States." Journal of Theoretical Politics 24(3):409-427.

Lichtenstein, P., P. Sullivan, S. Cnattingius, M. Gatz, S. Johansson, E. Carlstrom, C. Bjork, M. Svartengren, A. Volk, L. Klareskog, U. de Faire, M. Schalling, J. Palmgren \& N. Pedersen. 2006. "The Swedish Twin Registry in the Third Millennium: An Update." Twin Research and Human Genetics 9(6):875-882.

Littvay, Levente. 2012. "Do heritability estimates of political phenotypes suffer from an equal environment assumption violation? Evidence from an empirical study." Twin Res Hum Genet 15(1):6-14.

Littvay, Levente, Paul T Weith \& Christopher T Dawes. 2011. "Sense of Control and Voting: A Genetically-Driven Relationship." Social Science Quarterly 92(5):1236-1252.

Loehlin, J. 1996. "The Cholesky Approach: A Cautionary Note.” Behavior Genetics 26(1):66-69.

Loewen, P. \& C. Dawes. 2012. "The Heritability of Duty and Voter Turnout." Political Psychology $33(3): 363-373$.

Luciano, Michelle, Danielle Posthuma, Margaret J. Wright, Eco J.C. de Geus, Glen A. Smith, Gina M. Geffen, Dorret I. Boomsma \& Nicholas G. Martin. 2005. "Perceptual speed does not cause intelligence, and intelligence does not cause perceptual speed." Biological Psychology $70(1): 1-8$.

Luskin, R. 1990. "Explaining Political Sophistication.” Political Behavior 12(4):331-361.

Martin, N. \& L. Eaves. 1977. "The Genetic Analysis of Covariance Structure.” Heredity 38(1):79-95.

Martin, N., L. Eaves, A. Heath, R. Jardine, L. Feingold \& H. Eysenck. 1986. "Transmission of Social Attitudes." Proceedings of the National Academy of Sciences 83:4364-4368.

McClosky, H. 1958. "Conservatism and Personality." The American Political Science Review $52(1): 27-45$. 
Medland, S. \& P. Hatemi. 2009. "Political Science, Biometric Theory, and Twin Studies: A Methodological Introduction." Political Analysis 17:191-214.

Milbrath, L. \& M. Goel. 1977. Political Participation: How and Why Do People Get Involved in Politics? Chicago: Rand McNally.

Mondak, J. 2010. Personality and the Foundations of Political Behavior. Cambridge University Press.

Mondak, J. \& K. Halperin. 2008. "A Framework for the Study of Personality and Political Behaviour." British Journal of Political Science 38:335-362.

Mondak, J., M. Hibbing, D. Canache, M. Seligson \& M. Anderson. 2010. "Personality and Civic Engagement: An Integrative Framework for the Study of Trait Effects on Political Behavior." American Political Science Review 104(1):85-110.

Neale, M. \& L. Cardon. 1992. Methodology for Genetic Studies of Twins and Families. Dordrecht, The Netherlands: Kluwer.

Nie, N., J. Junn \& K. Stehlik-Barry. 1996. Education and Democratic Citizenship in America. Chicago: University of Chicago Press.

Oskarsson, Sven, Christopher Dawes, Magnus Johannesson \& PK Magnusson. 2012. "The genetic origins of the relationship between psychological traits and social trust." Twin Research and Human Genetics 15(1):21-33.

Petersson, O., A. Westholm \& G. Blomberg. 1989. Medborgarnas makt (Citizen Power). Stockholm: Carlssons.

Posthuma, D., L. Beem, E. de Geus, G. van Baal, J. von Hjelmborg, I. Iachine \& D. Boomsma. 2003. "Theory and Practice in Quantitative Genetics." Twin Research and Human Genetics $6(5): 361-376$.

Prior, M. 2010. "You've Either Got It or You Don’t? The Stability of Political Interest over the Life Cycle." Journal of Politics 72(3):747-766. 
Rotter, J. 1966. "Generalized Expectancies for Internal Versus External Control of Reinforcement." Psychological Monographs: General and Applied 80:1-28.

Shultziner, Doron. 2013. "Genes and Politics: A New Explanation and Evaluation of Twin Study Results and Association Studies in Political Science.” Political Analysis 21(3):350-367.

Smith, Kevin, John R. Alford, Peter K. Hatemi, Lindon J. Eaves, Carolyn Funk \& John R. Hibbing. 2012. "Biology, Ideology, and Epistemology: How Do We Know Political Attitudes Are Inherited and Why Should We Care?" American Journal of Political Science 56(1):17-33.

Spearman, C. 1904. "“General Intelligence” Objectively Determined and Measured." American Journal of Psychology 15:201-293.

Vecchione, M. \& G. Caprara. 2009. "Personality Determinants of Political Participation: The Contribution of Traits and Self-Efficacy Beliefs." Personality and Individual Differences 46:487492.

Verba, S., K. Schlozman \& H. Brady. 1995. Voice and Equality: Civic Volunteerism in American Politics. Harvard University Press.

Verhulst, B., L. Eaves \& P. Hatemi. 2012. "Correlation not Causation: The Relationship between Personality Traits." American Journal of Political Science 56(1):34-51.

Verhulst, B., P. Hatemi \& N. Martin. 2010. "The Nature of the Relationship Between Personality and Political Attitudes." Personality and Individual Differences 49(4):306-316.

Verhulst, Brad \& Ryne Estabrook. 2012. "Using genetic information to test causal relationships in cross-sectional data." Journal of Theoretical Politics 24(3):328-344.

Vinkhuyzen, A., N. Pedersen, J. Yang, S. Lee, P. Magnussen, W. Iacono, M. McGue, P. Madden, A. Heath \& M. Luciano. 2012. "Common SNPs explain some of the variation in the personality dimensions of neuroticism and extraversion." Journal of Translational Psychiatry 2:e102.

Visscher, Peter M., Jian Yang \& Michael E. Goddard. 2010. "A Commentary on 'Common SNPs Explain a Large Proportion of the Heritability for Human Height' by Yang et al. (2010)." Twin Research and Human Genetics 13(6):517-524. 
Weber, C., M. Johnson \& K. Arceneaux. 2011. "Genetics, Personality, and Group Identity." Social Science Quarterly 92(5):1314-1337.

Yang, Jian, Beben Benyamin, Brian McEvoy, Scott Gordon, Anjali Henders, Dale Nyholt, Pamela Madden, Andrew Heath, Nicholas Martin, Grant Montgomery, Michael Goddard \& Peter Visscher. 2010. "Common SNPs explain a large proportion of the heritability for human height." Nature Genetics 42(7):565-569.

Yang, Jian, S. Hong Lee, Michael E. Goddard \& Peter M. Visscher. 2011. "GCTA: A Tool for Genome-wide Complex Trait Analysis." American Journal of Human Genetics 88(1):76-82. 